ISSN: 2146-3042

DOI:

\title{
Stok Kontrolünde ABC ve VED Analizi Yöntemlerinin Kullanılması: Bir Üniversite Hastanesi Covid-19 Servislerinde Uygulama*
}

Ersin KORKMAZ** Mehmet GÜNER ${ }^{* * *}$

\section{ÖZET}

Sağllk işletmelerinde stok yönetimi sağlık hizmetlerinin etkin bir şekilde sunulması için önem arz etmektedir. Özellikle, pandemi gibi olağanüstü dönemlerde artan belirsizlikle birlikte stokların temini, saklanması ve kullanımı daha da önemli hale gelmektedir. Bu çalışmanın amacı, pandemi sürecinin beraberinde getirdiği belirsizlik koşullarında bir kamu hastanesinde kullanilan tıbbi sarf malzeme stok harcamaların stok kontrol tekniklerinden Always Better Control (ABC), Vital-Essential-Desirable (VED) ve ABC-VED Matris yöntemlerini kullanarak sinıflandirmak ve hastanelerde etkin bir stok yönetimi için en uygun yöntemi tespit etmektir. Çalışmada, hastanenin Covid-19 servislerinde 2020 yılında kullandiğı tıbbi sarf malzemeler öncelikle ABC analizi ile maliyet kriterine göre, VED analizi ile hasta hayatı için ifade ettiği önem kriterine göre sinıflandırlmuştır. ABC-VED matris yöntemiyle ise her iki kriter birlikte ele alınmış ve tıbbi sarf malzemeler 3 kategoriye ayrılmıştır. Kategori I'de bulunan ve sikı stok kontrolüne tabi tutulması gereken malzeme tutarı 579.491,98 TL $(\% 79,96) ;$ Kategori II'de yer alan ve orta stok kontrolüne tabi olmasl gereken malzeme tutarl 126.476,92 TL $(\% 17,45)$ ve Kategori III'te yer alan ve düşük stok kontrolüne tabi tutulması gereken malzeme tutarı ise 18.781,46 TL (\%2,59)'dir. Çalışma sonucunda, kullanılan sarf malzemelerin maliyet ve önem düzeylerinin değişstiği pandemi döneminde, etkin bir stok yönetimi için sadece maliyet veya hayati önem kriterini dikkate almak yerine her iki kriterin birlikte değerlendirildiği ABCVED matris yönteminin kullanılması önerilmiştir.

Anahtar Kelimeler: Stok Yönetimi, ABC Analizi, VED Analizi, ABC-VED Matrisi Analizi.

JEL Sinıflandırması: H51, I11, M41, M11.

\section{Using ABC and VED Analysis Methods in Stock Control: Application in A University} Hospital Covid-19 Services

\section{ABSTRACT}

Stock management in health enterprises is important for the effective delivery of health services. In particular, with the increasing uncertainty in extraordinary periods such as pandemics, the supply, storage and use of stocks becomes even more important. The aim of this study; to classify the stock expenditures of medical consumables used in a public hospital under the uncertainties brought by the pandemic process, using stock control techniques $A B C, V E D$, and ABC-VED Matrix; and to determine the most appropriate method for effective stock management. In the study, the medical consumables used by the hospital in Covid-19 services in 2020 were classified according to the cost criteria with ABC analysis, and according to the important criterion for patient life with VED analysis. With the ABC-VED matrix method, both criteria were considered together and medical consumables were divided into 3 categories. The amount of material in Category I that must be subject to strict stock control is 579,491.98 TL (79.96\%); The amount of material in category II that must be subject to medium stock control is 126,476.92 TL (17.45\%), and the amount of material in category III that must be subject to low stock control is 18,781.46 TL (2.59\%). As a result of the study, it has been suggested to use the ABC-VED matrix method, in which both criteria are evaluated together, instead of considering only the cost or vitality criteria for effective stock management during the pandemic period when the cost and importance levels of the consumables used to change.

Keywords: Inventory Management, ABC Analysis, VED Analysis, ABC-VED Matrix Analysis.

JEI Classification: H51, I11, M41, M11.

* Bu çalışma, 4-7 Kasım 2021 tarihlerinde yapılan 8. Uluslararası Muhasebe ve Finans Araştırmaları Kongresinde özet bildiri olarak sunulmuştur.

Makale Gönderim Tarihi: 17.11.2021, Makale Kabul Tarihi: 07.01.2022, Makale Türü: Vaka Analizi

** Doç. Dr., Erzincan Binali Yıldırım Üniversitesi, ekorkmaz@erzincan.edu.tr, ORCID: 0000-0002-6787-5368

*** Dr. Öğr. Üyesi, Erzincan Binali Yıldırım Üniversitesi, mguner@erzincan.edu.tr, ORCID: 0000-0002-95231519 


\section{GİRiş}

Sağlık sektöründe sağlık hizmetleri başlığı altında birçok hizmet kalemini sıralamak mümkündür. Laboratuvar hizmetleri, poliklinik hizmetleri, görüntüleme hizmetleri, araştırma hizmetleri ve eğitim hizmetleri gibi hizmetler bunlardan bazılarıdır. Bu hizmetlerin, herhangi bir gecikme yaşanmadan kesintisiz ve kaliteli bir şekilde sunulması hizmet alıcıları için hayati derecede önem taşımaktadır. Özellikle belirsizliğin, yoğunluğun ve yönetilmesi zor risklerin artığ 1 Covid-19 pandemisi döneminde sunulan sağlık hizmetlerinin kalitesi, güvenilirliği ve sürekliliği daha da önem kazanmıştır. Bu öneme binaen sağlık sektöründen beklentilerin diğer sektörlere nazaran daha yüksek olduğu söylenebilir.

Sağlık işletmelerinin faaliyet alanlarının geniş bir yelpazede olması sağlık hizmetinin üretimi esnasında birçok girdiye ihtiyaç duyulmasına neden olmaktadır. Diğer bir ifadeyle, sağlık hizmetlerinin başarılı bir şekilde sunulabilmesi için çok çeşitli ve özellikli mal ve malzeme girdileriyle çalışılması gerekir. Sağlık kuruluşlarının tıbbi malzeme harcamaları toplam harcamaların önemli bir kısmını oluşturmaktadır. Dolayısıyla, tıbbi sarf malzemeler için ayrılmış olan kaynakların en etkin şekilde kullanılmasını temin etmek için etkin bir stok yönetim sürecinin yürütülmesi gerekmektedir. Özellikle pandemi gibi olağanüstü dönemlerde, sağlık kuruluşlarından talep edilen hizmet sayısının öngörülemez şekilde artması neticesinde, tüketim miktarlarında önemli değişikliklerin olduğu tıbbi sarf malzemelerin maliyeti, tedariki ve tedarik süresi gibi hususlar daha da önem kazanmaktadır. Olağanüstü dönemlerde, hastanelerde sunulan hizmetlerde kilit rol oynayan mal ve malzeme stokları etkin ve verimli bir şekilde yönetilerek hizmetin aksamaması sağlanmalıdır. Bunun başarılabilmesi ancak çok iyi kurgulanmış bir stok yönetimi ile mümkündür. Bu durum sağlık kurumlarındaki stok yönetiminin önemini ortaya koymaktadır.

Sağlık kuruluşlarında hizmet sunumu için kullanılacak malzemelerin tespit edilmesi, hangi malzemeye ne zaman ve ne kadar ihtiyaç duyulacağının tahmin edilmesi gerekmektedir. Bu gereklilik, Covid-19 pandemisi gibi öngörülemeyen ve yönetilmesi güç olan dönemlerde daha da önemli bir hal almıştır. Stoklara gereğinden fazla yatırım yapılması sağlık kuruluşlarının karlılığının azalmasına ve sermaye yetersizliklerine neden olabilir. Öte yandan, yetersiz yatırım yapılması ise sunulan sağlık hizmetlerinin sürekliliğinin sağlanmasını önleyebilir. Tüm bu kararların isabeti bir şekilde verilebilmesi, stokların maliyetler ve hayati önem kriterleri dikkate alınarak etkin bir şekilde yönetilmesi için bazı yöntemler geliştirilmiştir. ABC (Always Better Control) Yöntemi, VED (Vital-Essential-Desirable) Yöntemi ve ABC-VED Matrisi yöntemi bunlardan bazılarıdır.

Sağlık işletmelerinde kullanılan tıbbi sarf malzemeleri, hem maliyetleri hem de hasta hayatı için taşıdıkları önem açısından değerlendirilmeli ve yönetilmelidir. Sadece maliyetin dikkate alındığı durumlarda hasta hayatı için önem arz eden stokların temini ve kullanımında yaşanacak sorunlar sağlık hizmeti sunumunun aksamasına yol açabilecektir. Öte yandan, sadece hayati önem kriterine göre stok yönetimi yapıldığında ise sağlık kuruluşu gereksiz maliyetler ve atıl stoklarla karşı karşıya kalabilecektir. Bu çerçevede çalışmada, bir üniversite hastanesinde kullanılan tıbbi sarf malzeme stokları için yapılan harcamaların stok kontrol tekniklerinden ABC, VED ve ABC-VED matris yöntemleri kullanılarak sınıflandırılması, bu suretle maliyet ve hayati önem kriterlerine göre en uygun stok kontrol yönteminin tespit edilmesi amaçlanmıştır. Araştırma, Erzincan Binali Yıldırım Üniversitesi, Mengücekgazi 
Eğitim ve Araştırma Hastanesi Covid-19 servislerinde 2020 y1lında kullanılan tıbbi sarf malzeme stokları dikkate alınarak yürütülmüsştür.

\section{KAVRAMSAL ÇERÇEVE VE LITERATÜR}

Hastaneler sağlık sisteminin en önemli parçalarından biri olan, hizmet üretiminin büyük bir kısmını üstlenen, birey ve toplum sağlığının korunması ve geliştirilmesinde önemli rol oynayan hizmet işletmeleridir. Hastaneler doğrudan hasta tedavisi ve bakımını amaçlamakla birlikte eğitim ve araştırma faaliyetleri de öncelikli amaçları arasında yer alan kuruluşlardır. Hizmet sunan kurumlar arasında yer alan hastaneler; kuruluş ve işletme sermayesi oldukça yüksek olan, farklı hizmet grupları ve eğitim düzeyine sahip personeli bulunan ve faaliyetlerinin yürütülmesinde ileri teknolojiyi kullanma gibi özellikleri bünyesinde bulunduran kuruluşlardır (Kılıç ve Öztürk, 2006:57). Sağlık nedeniyle yaşanan sorunların ertelenemez nitelikte olması, hastanelerin sağlık hizmetlerinin etkin ve verimli bir şekilde yürütülebilmesinde büyük önem taşıdığını göstermektedir (Böker ve Çetin, 2020: 181; Yarar ve İnce, 2017: 1-5).

Hastane işletmeleri kendi içerisinde alt sistemlerden oluşur. Her bir alt sistemin de kendine özgü işleyiş şekli ve özellikleri vardır. Söz konusu sitemlerin etkinliği de birbirine bağlıdır (Karagöz ve Yıldız, 2015:378). Bu durum sağlık hizmetlerini diğer hizmetlerden ayıran başlıca farklılıklar arasında sayılabilir. Diğer bir ifadeyle, kaliteli bir sağlık hizmetinin sunulabilmesi için birçok faaliyetin eş zamanlı yürütülmesi veya birçok faktörün birbirine entegre çalışması gerekir (Tengilimlioğlu,2015:192). Bu entegrasyonun sağlanabilmesi noktasında en önemli konulardan biri de sağlık hizmetlerinin üretiminde kullanılan tıbbı sarf malzeme stoklarının yönetilmesidir.

Stok, genel bir tanımla, belirli bir süre atıl durumda tutulan, kullanılmak veya satılmak amacıyla bulundurulan ve ekonomik değeri olan mal ve malzemeler olarak tanımlanabilir (Çelikçapa ve Şenol, 2015:107). Stok kavramı ile genellikle mal ve hizmet üretimi ve satış1 için ihtiyaç duyulan fiziksel varlıklar ifade edilmektedir (Tanyaş ve Baskak, 2013:124). Sağlık sektöründe stok kavramı ise, sunulan sağlık hizmetlerinin aksamadan sürdürülmesi amacıyla bulundurulan her türlü mal ve malzemeleri ifade etmektedir (Akman, 2003:16). Yapılan çalışmalar sağlık sektöründe stok maliyetlerinin toplam maliyetlerden \%10 ile \%18 arasında pay aldığını göstermektedir (Rachmania ve Basri, 2013:1). Hastaneler açısından bakıldığında ise stoklara yapılan harcamalar, toplam harcamaların yaklaşık \%30 ile \%40'ına denk geldiği ifade edilmektedir (Huarng, 1998:71). Sağlık harcamalarının önemli bir kısmından pay alan hastaneler, yüksek kaliteli ve düşük maliyetli bir sağlık hizmeti sunabilmek için kaynaklarını verimli kullanmak zorundadır. Özellikle, pandemi dönemiyle birlikte sağlık hizmetlerinde yaşanan yoğunluk ve maliyetlerdeki artışlar dikkate alındığında mevcut varlık ve kaynakların ekonomik ve amacına uygun kullanımının daha çok önem kazandığı söylenebilir.

Yukarıda verilen oranlardan hareketle stok kalemleri, hastaneler açısından çok önemli bir girdi kaynağı olarak değerlendirilebilir (Tengilimoğlu ve Yiğit, 2017: 162). Dolayısıyla hastanelerin stok yönetimini minimum maliyetle yürütebilmesi, talebe odaklı stokların minimum hatayla tahmini, rutin faaliyetlerin devamına imkânı veren stok miktarlarının doğru tespiti, siparişlerin uygun miktarda ve zamanda verilmesi gibi konular önem arz etmektedir (Türk ve Şeker, 2011:713). 
İnsan gücü ve tıbbi sarf malzemeler, hastane işletmelerinde hastaların teşhis ve tedavi hizmetlerinin etkin ve verimli bir şekilde sürdürülebilmesi için başlıca unsurlardır. Bu iki unsur, sunulan hizmetin kalitesini ve hastane işletmelerinin rekabet gücünü artırmaktadır. Özellikle ilaç ve tıbbi sarf malzeme stoklarının kalite ve rekabet gücüne istenilen düzeyde katkı sağlaması çok iyi tasarlanmış bir stok yönetimi ile mümkündür. Dolayısıyla hastanelerde direkt malzeme yönetimi anlamına gelen stok yönetimi; doğru malzemeyi doğru miktarda, doğru zamanda ve uygun maliyetle yine doğru yerde bulundurma amacını taşıyan politikalar doğrultusunda planlanmalıdır (Aytekin, 2009:113).

Hastane işletmelerinin toplam varlıkları içinde önemli bir pay alan stok kalemlerine gereğinden fazla yatırım yapılması hastanenin karlılığı üzerinde negatif etki yapabilir. Diğer taraftan, stok yönetim sürecinde optimal stok seviyesinin eksik veya yanlış tespit edilmesi kaynakların atıl kalmasına neden olabilir. $\mathrm{Bu}$ durum stokların işletmelerin finansal performansı üzerinde etkili olan önemli kalemler arasında olduğunun bir göstergesidir (Tersine ve Tersine, 1988: 3). Ayrıca, stoklara yetersiz yatırım yapılması halinde ise, özellikle hayati önem taşıyan sağlık hizmetlerinde sürekliliği sağlamada ciddi sorunlarla karşılaş1labilir. Yetersiz stok bulundurmanın maliyeti maddi olduğu kadar maddi olarak değeri ölçülemeyen ölüm gibi kayıplara da yol açabilir (Yiğit, 2014:106-107; Berman ve Weeks, 1992:307). Dolayısıyla stoklarla ilgili cevaplanması gereken her sorunun tüm işletmeler için, özellikle hastaneler için hayati önem taşıdığı söylenebilir.

Hastanelerde stok ve stoksuzluk maliyetlerini en düşük seviyede tutmak için hem maliyet hem de hayati öneme sahip olup olmama, bir başka ifade ile kritiklik durumuna göre sağlık hizmetlerinde kullanılan malzemelerin ve ilaçların stoklanması gerekir. Bunu başarılı bir şekilde uygulayabilmek için stok kontrol yöntemlerinden yararlanılmaktadır (Roy vd.,2010:11). Stokları etkin şekilde yönetmek için kullanılan birçok yöntem geliştirilmiştir. $\mathrm{ABC}, \mathrm{VED}$ ve ABC-VED Matris yöntemleri de bunlardan bazılarıdır.

Literatür incelendiğinde, sağlık kuruluşlarında ilaç ve tıbbi sarf malzeme stoklarını kapsayan stok yönetimini farklı yöntemler kullanmak suretiyle analiz eden birçok çalışma bulunmaktadır. Bu çalışmada, yöntem olarak ele alınan analizler kapsamında, sağlık işletmelerinde stok yönetimini ABC, VED ve ABC-VED Matris yöntemleri kullanarak ele alan çalışmalardan bazıları ifade edilmiştir.

Gupta ve diğ. (2007), bir hastanenin ilaç stoklarını ABC-VED matris analizi ile inceledikleri çalışmalarında, ilgili hastanede kullanılan 325 kalem ilacın \%70'ini A grubu, \%20'sini B grubu ve \%10'unu ise C grubu olarak sınıflamışlardır. Uzman görüşüne dayalı olarak yaptıkları VED analizinde ise söz konusu ilaçların sadece \%7,3'lük kısmının hayati öneme sahip V grubunda, \%49,3'lük kısmının gerekli ilaç olarak E grubunda ve \%43,3'ünün ise isteğe bağlı olarak bulundurulabilecek ilaç olarak $\mathrm{C}$ grubunda sınıflandırmışlardır. Çalışmada, iki tekniğin birleştirilmesi suretiyle ABC-VED matrisi oluşturulmuş ve ilaçların 68'i Kategori I, 159'u Kategori II ve 98'i ise Kategori III olarak sınıflandırılmıştır. Sonuç olarak, hastane yönetiminin daha iyi bir stok yönetimi için ABC-VED matrisinden hareketle Kategori I grubunda yer alan ilaçlara odaklanması gerektiği ifade edilmiştir.

Yiğit (2014), bir üniversite hastanesinde ABC-VED matris yöntemini kullanarak ilaç harcamalarını analiz etmiştir. ABC analizini kapsamında, ilaç harcamalarının yaklaşık \%90'lık kısmının en düşük maliyetli ilaçlar olarak ifade edilen C grubunda toplandığ 1 ; VED 
analizinde ise ilaçların büyük oranda bulundurulması gerekenlerin yer aldığı E grubunda sınıflandırıldığ 1 görülmüştür. ABC-VED matris yöntemine göre oluşturulan kategorilerde ise sirasıyla 358 adet $(\% 22,47), 700$ adet $(\% 70,58)$ ve 270 adet $(\% 6,96)$ ilaç bulunduğu ve hastanenin Kategori I'de yer alan 358 adet ilacı daha s1kı kontrol etmesi gerektiği ortaya konulmuştur.

Çabuk ve diğ. (2018) çalışmalarında, bir kamu hastanesinin 2016 yılı tüketilen tıbbi sarf malzemelerini ABC-VED matris yöntemiyle analiz etmeyi amaçlamışlardır. Hastanede kullanılan 168 kalem tıbbi sarf malzemenin 26's1 (\%15,48) A grubunda, 27'si $(\% 16,07)$ B grubunda ve $115^{\prime} \mathrm{i}(\% 68,45) \mathrm{C}$ grubunda sinıflanmıştır. VED analizine göre ise, $88(\% 52,38)$ malzeme hayati önem arz eden V grubunda, $23(\% 13,69)$ malzeme bulundurulması gereken malzemeleri ifade eden E grubunda ve $56(\% 33,33)$ malzeme ise isteğe bağl1 olarak bulundurulan malzemeler olarak kabul edilen D grubunda yer almıştır. Söz konusu malzemeler ABC-VED matris yöntemiyle kategorilere ayrılmış ve hastane yönetiminin Kategori I'de yer alan malzemeleri daha sıkı takip etmesi gerektiği ifade edilmiştir.

Yılmaz (2018), İstanbul'da faaliyet gösteren özel bir hastanenin 2016 yılı ilaç tüketim verilerini, ABC ve VED analizleri kullanmak suretiyle ilaçlar için katlanılan yıllık harcama tutarı üzerinden sınıflandırmayı ve bu sayede hastane yönetimi için optimal ilaç depolama miktarının tespitine katkı sağlamayı amaçlamışlardır. ABC-VED matris yöntemine göre, I. kategoride 298, II. kategoride 446, III. kategoride 163 ilaç bulunduğunu ve sonuç olarak yapılan analizlerin özellikle toplam harcamalar içinde önemli bir tutarı ifade eden ilaç harcamaları için güvenlik stok düzeylerinin belirlenmesinde yönetime katkı sağlayacağını belirtmişlerdir.

Fitriana ve diğg. (2018), Endonezya'da bir veteriner fakültesi hastanesi stok kalemlerine ilişkin harcama tutarı ve tüketim miktarlarını, stok kontrol tekniklerini kullanarak analiz etmeyi amaçlamışlardır. ABC-VED matris analizinde ilaç kalemlerinin miktar olarak \%25,13, \%67,02 ve \%7,85'inin sirasiyla kategori I, II ve III'te yer aldı̆̆ 1 ; maliyet olarak ise kategorilerde yer alan harcama tutar yüzdelerinin sirasıyla $\% 74,17, \% 24,57$ ve $\% 1,26$ olduğu hesaplanmıştır. Sonuç olarak, ABC-VED matris analizinin, hastane için ilaç stoklarının yönetiminde benimsenebileceği ve böylece ilaçların mevcudiyetinin ve hasta bakım kalitesinin verimli bir şekilde planlanabileceği ortaya konulmuştur.

Taddele ve diğ. (2019), Etiyopya'da bulunan ikinci düzey bir hastane olan Arbaminch hastanesinin eczanesinde yer alan ilaç stoklarının ABC-VED matris analizi kullanılarak analiz edilmesini ve sıkı yönetim kontrolü gerektiren ilaçların belirlenmesini amaçlamışlardır. Sonuç olarak, Kategori I'e ait ilaçların sıkı envanter kontrolüne tabi tutulması gerektiği, Kategori II ve Kategori III'te yer alan ilaçların ise sırasıyla orta ve alt düzeyde kontrol gerektirdiği; ikinci basamak sağlık kuruluşunda kaynakların verimli kullanılması, israfın ve stokun giderilmesi için ABC-VED tekniklerinin uygulanmasının yerinde olacağı ifade edilmiştir.

Hussain ve diğ. (2019), Hindistan'da bir sağlı kurumunun cerrahi sarf malzeme stoklarını analiz etmek için ABC, VED veya ABC-VED matris yöntemlerini kullanmışlardır. Çalışma, söz konusu malzemelerin sınıflandırılmasının yanında tedarik sürelerinin hesaplanmasını da amaçlamıştır. ABC analizi, malzemelerin 35 (\%14)'inin A, 52 (\%21)'sinin B ve 171 (\%69)'inin C grubuna; VED analizi ise \%73'ünün V, \%26'sinın E ve \%1'inin ise D grubuna dahil olduğunu ortaya koymuştur. Sonuç olarak, hastane yönetimlerinin stok diş1 
kalma sayısını azaltmak ve tedarik süresini kısaltmak amacıyla stok kontrol tekniklerinden yararlanması gerektiği tespit edilmiştir.

Yiğit ve Yiğit (2019) Kamu Hastaneleri Genel Müdürlüğüne (KHGM) bağlı hastanelerde tüketilen tıbbı malzemeleri ABC, VED ve ABC-VED matris yöntemlerine göre analiz etmeyi amaçlamışlardır. Yapılan analizler neticesinde, $\mathrm{ABC}$ yöntemine göre tıbbi malzemelerin tutar olarak \%69,63’ü A grubu, \%20,04'ü B grubu ve \%10,32'si C grubu olarak belirlenmiştir. VED yöntemine göre ise $\mathrm{V}, \mathrm{E}$ ve $\mathrm{D}$ grubunda yer alan malzeme tutar yüzdeleri sırasıyla \%50,95, \%25,72 ve \%23,33 olarak tespit edilmiştir. ABC-VED matris yönteminde ise Kategori I'de toplam tüketilen malzeme tutarının \%80,35'i, Kategori II'de \%18,16's1 ve Kategori III'te ise \%1,49'u yer almıştır. Sonuç olarak, hastanelerde tıbbı malzeme stoklarının maliyet ve kritiklik özelliklerine göre etkin olarak yönetilmesi için ABC, VED ve ABC-VED matris yöntemlerinin bir karar aracı olarak kullanılabileceği önerilmiştir.

Işıkçelik ve diğ. (2019) Sağlık Bakanlığı'na bağlı 200 yataklı bir hastanenin 2017 yılı ilaç stoklarını ABC, VED ve ABC-VED stok kontrol yöntemleriyle analiz etmeyi amaçladıkları çalışmalarında, $\mathrm{ABC}$ yönteminin stokları sadece parasal açıdan sahip oldukları öneme göre, VED yönteminin sadece hayati önem açısından; ABC-VED yönteminin ise stokları hem maddi hem de hayati önem açısından kombine ederek sınıflandırdığını ifade etmişlerdir. Sonuç olarak, hastane yönetiminin, stok kontrolünü ifade edilen kriterlere göre elde edilen bulguları dikkate alarak yürütmesi gerektiğini vurgulamışlardır.

Tisinli ve Savaş (2019), çalışmalarında İstanbul'da 101 yataklı ve dört ameliyat servisi olan özel bir hastanenin ameliyat servislerinde kullanılan tek kullanımlık tıbbi sarf malzemeleri dikkate alarak ABC, VED ve ABC-VED matris analizi kullanmak suretiyle stok kontrol analizi yapmayı amaçlamışlardır. Malzemelerin her analiz kapsamında sınıflandırıldığ 1 çalışma neticesinde, ameliyat servislerinde etkin bir stok yönetimi uygulayarak maliyetlerin düşürülebileceği ve stokların fiziksel olarak daha etkin yönetilebileceği; ameliyatların daha ekonomik ve etkin bir şekilde gerçekleştirilebilmesi için sorumluların $\mathrm{ABC}$, VED ve $\mathrm{ABC}-\mathrm{VED}$ matris analizi yöntemlerini sürekli olarak kullanmaları gerektiği ifade edilmiştir.

Böker ve Çetin (2020), Trakya bölgesinde hizmet veren özel bir hastanenin 2017 yılı ilaç stokunu maliyet, tüketim, kritiklik ve tedarikçi riski kriterleri çerçevesinde sınıflandırmayı amaçlamışlardır. ABC-VED, Analitik Hiyerarşi Prosesi (AHP) ve TOPSIS yöntemlerinin kullanıldığı çalışma sonucunda, hastanelerin tedarik süreçlerindeki aksaklıklardan kaynaklanabilecek riskleri yönetebilmek için stok sınıflandırmasına önem verilmesi gerektiği, aksi durumda hem hayati önem taşıyan ilaçların temin süreçlerinde sorunlar yaşanabileceği hem de yüksek maliyetlerle karşılaşıllabileceği ifade edilmiştir.

Çil Koçyiğit ve Doğan Çulha (2020) çalışmalarında, özel bir hastanenin yoğun bakım servisindeki tıbbi sarf malzeme tüketimlerinin toplam hastane bütçesi içindeki payını belirlemek ve söz konusu malzeme stoklarını ABC-VED ve ABC-VED matris yöntemi ile analiz etmeyi amaçlamışlardır. Çalışma sonucunda; ABC-VED matris analizi neticesinde toplam tüketilen malzeme tutarının \%78,58'i Kategori I'de, \%19,07'si Kategori II'de ve \%2,36'sı da Kategori III'te sinıflandırılmıştır. 
Literatür araştırmasında, sağlık kuruluşlarında kullanılan ilaç ve tıbbi sarf malzeme stoklarının yönetiminde $\mathrm{ABC}, \mathrm{VED}$ ve $\mathrm{ABC}-\mathrm{VED}$ matris yöntemlerinin kullanılmasını konu edinen ve farklı türdeki sağlık kuruluşlarında tüketilen stokların incelendiği görülmektedir. Yapılan çalışmaların büyük çoğunluğunda hastanelerin bütününde tüketilen sarf malzemelerin veya ilaçların analiz edildiği görülmüştür. Ancak, bu araştırmanın uygulaması kapsamında verileri kullanılan hastanenin yönetimi ile yapılan görüşmelerde, her servisin ihtiyaçları farklı olduğundan stokların servisler bazında talep ve takip edildiği, hastanenin bütünü için uygulanacak tek bir stok takip prosedürünün gereksiz stok maliyetlerine yol açabileceği tespit edilmiştir. Dolayısıyla, bu çalışmada hastanenin bütününde tüketilen sarf malzeme stoklarından ziyade tek bir serviste tüketilen malzemelerin sınıflandırılmasının daha doğru sonuçlar ortaya koyacağ 1 düşünülmüştür. Öte yandan, Covid-19 pandemi sürecinde sağlık kuruluşlarının işleyişinde önemli değişiklikler ve aşırı yoğunluklar ortaya çıkmış ve söz konusu servislerde tüketilen tıbbi sarf malzeme stoklarının yönetilmesi aşırı derecede önem kazanmıştır. Bu bağlamda, birçok hastanede malzemelerin servis bazında takip edilmesi ve pandemi sürecinin beraberinde getirdiği koşullar dikkate alınarak çalışmada Covid-19 servislerinde tüketilen tıbbi sarf malzemelerin esas alınması ve bu suretle literatüre katkı sağlanması hedeflenmiştir.

\section{METODOLOJİ}

Çalışmanın bu kısmında araştırmanın amacı, kapsamı, yöntemi ve bulgularına ilişkin değerlendirmeler sunulmuştur.

\subsection{Araştırmanın Amacı, Kapsamı ve Yöntemi}

Kavramsal çerçeve ve literatür incelendiğinde sağlık kuruluşlarında stok yönetiminin sunulan sağlık hizmetlerinin kalitesi ve sürekliliği üzerinde önemli etkisi olduğu, ayrıca maliyetlerin kontrol altında tutulması için de önemli bir araç olduğu görülmektedir. Sürdürülebilir sağlık hizmeti sunumu, ihtiyaç duyulan tıbbi malzemelerin doğru zamanda, doğru miktarda temin edilmesini ve stoklanmasını gerektirmektedir. Bununla birlikte, bir hizmet işletmesi olan sağlık kuruluşlarının yüksek maliyetler nedeniyle karlılığının düşmesi de istenmeyen bir durumdur. Olağan koşullar altında dahi önem arz eden stok yönetimi, salgın hastalıkların arttığı ve pandemi haline geldiği dönemlerde daha da kritik bir hal almaktadır. Bu kapsamda, bir üniversite hastanesinin Covid-19 servislerinde kullanılan tıbbi sarf malzeme stokları için yapılan harcamaların stok kontrol tekniklerinden ABC, VED ve ABC-VED matris yöntemleri ile analiz edilip maliyet ve hayati önem kriterlerine göre sınıflandırılması ve en uygun stok kontrol yönteminin tespit edilmesi bu çalışmanın amacı olarak belirlenmiştir.

Çalışma kapsamında veri setini oluşturmak üzere ilgili hastanenin 2020 yılında tükettiği tıbbi sarf malzemelerin ayrıntılı dökümü elde edilmiştir. Veri seti incelendiğinde ilgili hastanenin Covid-19 servislerinde 2020 yılında 203 çeşit malzeme kullanılmıştır ve kullanılan malzemeler için yapılan toplam harcama tutarı 724.750,37 TL'dir. Bu tutar, hastanenin sadece tek bir servisinde bir yılda kullanılan malzeme tutarının büyüklüğünü ortaya koyması bakımından önem arz etmektedir.

Literatürde stok kontrolü için geliştirilen birçok yöntem mevcuttur. Bu çalışmada, araştırmada kullanılan $\mathrm{ABC}$, VED ve $\mathrm{ABC}$-VED matris yöntemleri hakkında bilgi verilmiştir. 


\subsection{ABC (Always Better Control) Yöntemi}

İngilizce "Always Better Control (Daima Daha İyi Kontrol)" ifadesindeki kelimelerin baş harflerinin bir araya getirilmesi ile ifade edilen yöntemin çıkış noktası verimliliği artırmak ve daha iyi kararlar almak için genellikle yönetim, ekonomi ve işletmede kullanılan Pareto İlkesine dayanmaktadır. 80-20 kuralı olarak da bilinen ve İtalyan iktisatçı Vilfredo Pareto tarafından geliştirilen Pareto ilkesine göre, birçok olayda sonuçların yaklaşık \%80'i, nedenlerin \%20'si tarafından üretilmektedir (Dunford, 2014: 141). ABC analizi, uygulama kolaylığı sayesinde oldukça yaygın bir şekilde kullanılmakta olan bir stok sınıflandırma ve yönetim tekniğidir. ABC analizi kullanılarak yapılan sınıflandırmada stok kalemlerinin belli bir dönemdeki maliyetleri belirlenir ve stoklar için yapılan toplam harcama içerisinde her bir stok kaleminin kümülatif oranı incelenerek sınıflandırılmaktadır (Dağsuyu, 2019: 213). Sınıflandırma neticesinde stoklar A, B ve C olmak üzere oransal olarak 3 gruba ayrılır (Şekil 1).

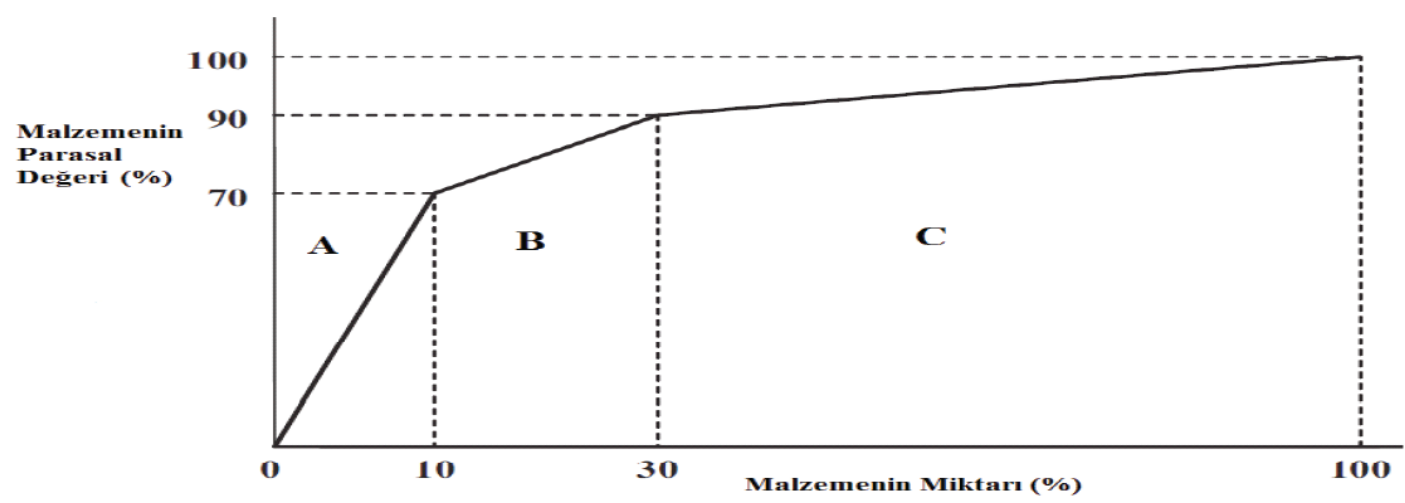

Şekil 1. ABC Yöntemi

Kaynak: Yiğit, 2014: 109.

A grubu stoklar, toplam stok harcamasının kümülatif olarak \%70'ini toplam stok miktarının ise \%10'unu oluşturmaktadır. B grubu stoklar, toplam stok harcamasının ve toplam stok miktarının kümülatif olarak \%20'sini; C grubu stoklar ise kümülatif olarak toplam stok harcamasının \%10'unu toplam stok miktarının ise \%70'ini oluşturmaktadır (Gupta vd., 2007: 325). A grubunda bulunan stokların oldukça yüksek maliyetli olması söz konusu stokların asgari düzeyde bulundurulmasını ve dikkatli bir şekilde kontrol edilmesini gerektirmektedir. Orta seviyede maliyet ve miktara sahip olan stokların yer aldığı B grubunda orta düzeyde emniyet stoğu bulundurulmalı ve stok kontrolü çok sıkı olmamalıdır. Maliyetin oldukça düşük olduğu C grubunda ise çok sayıda stok bulunmaktadır. Söz konusu stokların maliyeti çok düşük olduğundan fazlasıyla stok yapılabilmekte ancak stok kontrolü düşük seviyede tutulmaktadır (Reddy, 2008:128; Manhas et al., 2012: 183; Yiğit ve Yiğit, 2019: 256).

\subsection{VED (Vital-Essential-Desirable) Yöntemi}

"Vital (Hayati), Essential (Gerekli), Desirable (İsteğe Bağlı)" kelimelerinin baş harfleri ile adlandırılan VED yöntemi, stokları mal ve hizmet üretiminde sahip oldukları kritiklik düzeyine göre sınıflandırmaktadır. Bu yöntemde malzemeler V (Vital), E (Essential) 
ve D (Desirable) olmak üzere üç grupta toplanır ve kritiklik düzeyleri şu şekilde ifade edilmektedir (Gupta et al. 2007):

V (Vital): Yokluğunda işletmenin mal veya hizmet üretimini gerçekleştiremediği, hayati önem taşıyan stoklardır.

E (Essential): Yokluğunda alternatifler stoklar ile işletmenin mal veya hizmet üretimini devam ettirebildiği fakat ürün ve hizmet kalitesinden ödün verilmesinin gerekebileceği stoklardır.

D (Desirable): Yokluğunda işletmenin mal veya hizmet üretimini sürdürebildiği ve isteğe bağlı olarak işletmede bulundurulan stoklardır.

\subsection{ABC-VED Matris Yöntemi}

Mal veya hizmet üretiminde bütün stok kalemlerinin ayrı ayrı izlenmesinin getirdiği zorluktan dolayı, stok yönetimi için önem arz eden maliyet ve kritiklik unsurları dikkate alınarak hem stok harcamalarının büyük bir bölümünü oluşturan hem de üretim için son derece önemli olan stoklar belirlenerek bu doğrultuda bir stok yönetim sistemi uygulanmalıdır. ABC ve VED yöntemlerinin ortaya koyduğu stok sinıflandırmaları çerçevesinde stokların hem parasal büyüklük hem de kritiklik değerlerini bir arada değerlendirmek maliyet ve hayati önem ikileminden kurtularak stokların daha etkin bir şekilde yönetilmesini sağlayacaktır (Işıkçelik vd., 2019: 309).

ABC-VED yönteminde stoklar, ABC ve VED analizlerinden elde edilen bulguların gruplandırılmasıyla üç farklı kategori altında toplanmaktadır. Tablo 1, oluşturulan kategorileri ve her bir kategoride yer alan grupları göstermektedir.

Tablo 1. ABC-VED Matrisi

\begin{tabular}{|c|c|c|c|}
\hline ABC & $\mathbf{V}$ & $\mathbf{E}$ & $\mathbf{D}$ \\
\hline $\mathbf{A}$ & $\mathrm{AV}$ & $\mathrm{AE}$ & $\mathrm{AD}$ \\
\hline $\mathbf{B}$ & $\mathrm{BV}$ & $\mathrm{BE}$ & $\mathrm{BD}$ \\
\hline $\mathbf{C}$ & $\mathrm{CV}$ & $\mathrm{CE}$ & $\mathrm{CD}$ \\
\hline
\end{tabular}

Kaynak: Işıkçelik vd., 2019: 309.

Tablo 1'de yer alan matristen hareketle oluşturulan 3 kategori ve kategorilerde bulunan stok grupları şu şekildedir (Yiğit ve Yiğit, 2019: 257):

I. Kategori (AV, AE, AD, BV, CV): Bu grupta yer alan stoklar hem mal veya hizmet üretimi için hayati önem taşımakta hem de yüksek maliyet ihtiva etmektedir. Dolayısıyla, makul bir fiyatla temin edilmesi, stok seviyelerinin sürekli bir şekilde sıkı olarak izlenmesi ve denetlenmesi gerekmektedir. 
II. Kategori (BE, CE, BD): Mal ve hizmet üretiminin kaliteli bir şekilde sürdürülebilmesi için gerekli olan stokların yer aldığg kategoridir. Orta düzey maliyete sahip stokların bulunduğu grubun stok kontrolü de orta seviyede yapılmalıdır.

III. Kategori (CD): Bu grupta bulunan stoklar ise hem maliyet hem de önem düzeyi açısından düşük seviyeli stoklardır. Bulundurulması isteğe bağlı stoklar olduğundan stok kontrolünün düşük düzeyde yapılması gerekmektedir.

Veri seti analize hazır hale getirildikten sonra, ABC yöntemine göre 2020 y1lı toplam sarf malzeme harcamalarının yaklaşık \%70'lik kısmı A grubuna, \%20'lik kısmı B grubuna ve \%10'luk kısmı C grubuna ayrılmıştır. VED yöntemine göre sarf malzemelerin gruplandırılması amacıyla 3 farklı uzmandan görüş alınmış ve malzemeler ilgili servislerde tedavi gören hastaların tedavileri için taşıdıkları hayati önem düzeyine göre V (Vital), E (Essential) ve D (Desirable) gruplarına ayrılmıştır. Son olarak, ABC-VED Matris yöntemi kullanılarak diğer yöntemlerden elde edilen bulgular bir araya getirilmiş ve tıbbi sarf malzemeler maliyet ve kritiklik seviyelerine göre 3 kategoriye ayrılmıştır.

\subsection{Bulgular}

Hastanenin Covid-19 servislerinde kullanılan tıbbi sarf malzemeleri toplam harcama içinde kümülatif olarak en yüksekten en düşüğe göre tespit ederek gruplandıran $\mathrm{ABC}$ analizinden elde edilen bulgular Tablo 2'de sunulmuştur.

Tablo 2. ABC Analizi

\begin{tabular}{|c|c|c|c|c|}
\hline ABC & \multicolumn{2}{|c|}{ Stok Miktarı } & \multicolumn{2}{c|}{ Stok Değeri } \\
\hline & Sayı & \% & Tutar (TL) & \% \\
\hline A & 14 & 6,9 & $499.371,45$ & 68,9 \\
\hline B & 23 & 11,3 & $151.467,01$ & 20,9 \\
\hline C & 166 & 81,8 & $73.911,91$ & 10,2 \\
\hline Toplam & $\mathbf{2 0 3}$ & $\mathbf{1 0 0}$ & $\mathbf{7 2 4 . 7 5 0 , 3 7}$ & $\mathbf{1 0 0}$ \\
\hline
\end{tabular}

ABC yöntemine göre, toplam 203 kalem sarf malzemenin \%6,9’u A grubu, \%11,3’ü B grubu ve \%81,8’i ise C grubu tıbbi sarf malzemeler arasında gruplanmıştır. 2020 yılında sarf malzemeler için yapılan 724.750,37 TL'lik harcamanın \%70,46 (499.371,45 TL)'sı A grubu, \%20,9 (151.467,01 TL)'u B grubu, \%10,2 (73.911,91 TL)'si ise C grubu sarf malzemelerden oluşmaktadır. A grubunu oluşturan sarf malzemelerden kümülatif olarak en yüksek maliyeti ihtiva eden ilk 3'ü sırasıyla; 118.762,74 TL maliyet ile “Yüksek Frekans Akışlı Diffüsif Sürekli Pozitif Havayolu Terapi Seti (EZPAP)", 74.742,97 TL maliyet ile "Non-Steril Cerrahi Önlük-XL" ve 43.480,03 TL maliyet ile "Maske N95-FPP3" olarak tespit edilmiştir. B grubunda yer alan ilk 3 sarf malzeme; 13.252,72 TL maliyet ile "Kanül I.V. No:22(Mavi)”, 12.787,20 TL maliyet ile "Disposable Mekanik Ventilatör" ve 12.149,16 TL maliyet ile "Damla Ayar Seti” olarak belirlenmiştir. Son olarak C grubu sarf malzemelerden en yüksek maliyetli ilk 3’ü; 2.546,75 TL maliyet ile “Ambu Seti Yetişkin”, 2.151,36 TL maliyetli "Saatli İdrar Torbası” ve 2.088,40 TL maliyetli “Koruyucu Gözlük” olmuştur. 
Tıbbi sarf malzemelerin Covid-19 servislerinde tedavi gören hastalar için ifade ettiği kritiklik düzeyine göre gruplandırılmasını sağlayan VED analizi bulguları Tablo 3'te sunulmuştur.

Tablo 3. VED Analizi

\begin{tabular}{|c|c|c|c|c|}
\hline \multirow{2}{*}{ VED } & \multicolumn{2}{|c|}{ Stok Miktarı } & \multicolumn{2}{c|}{ Stok Değeri } \\
\hline & Sayı & \% & Tutar (TL) & \% \\
\hline V & 69 & 33,99 & $139.254,92$ & 19,21 \\
\hline E & 88 & 43,35 & $539.458,02$ & 74,43 \\
\hline D & 46 & 22,66 & $46.037,43$ & 6,36 \\
\hline Toplam & $\mathbf{2 0 3}$ & $\mathbf{1 0 0}$ & $\mathbf{7 2 4 . 7 5 0 , 3 7}$ & $\mathbf{1 0 0}$ \\
\hline
\end{tabular}

VED yöntemine göre, 203 kalem tıbbi sarf malzemenin miktar olarak \%33,99’u V grubunda, \%43,35'i E grubunda ve \%22,66'sı D grubunda sınıflandırılmıştır. 2020 yılında sarf malzemeler için yapılan 724.750,37 TL'lik harcamanın \%19,21 (139.254,92 TL)'i V grubunda, \%74,43 (539.458,02 TL)'ü E grubunda ve \%6,36 (46.037,43 TL)'s1 ise D grubunda yer almıştır. "Disposable Mekanik Ventilatör”, "Forseps Yöntemli Perkütan Trakeostomi Seti” ve "Maske 3 Katl Lastikli Disposable (Tek Kullanımlık)” V grubunu oluşturan tıbbi sarf malzemelere; "Antimikrobiyal Gümüş İçerikli Vakum Yardıml Orta Kapama Seti (OR2160)”, "Vinil Pudrasiz Non Steril Muayene Eldiveni” ve "Kan Kültür Şişesi” E grubu sarf malzemelere, "Gazlı Bez", "Pamuk" ve "Vakumlu İdrar Torbası" ise D grubu malzemelere örnek olarak ifade edilebilir.

Tablo 4'te ABC ve VED yöntemlerinin bir araya getirilmesi ile oluşturulan matris bulguları yer almaktadır.

Tablo 4. ABC-VED Matris Analizi

\begin{tabular}{|c|c|c|c|c|c|c|c|c|c|c|c|}
\hline \multirow{2}{*}{$\begin{array}{l}\text { ABC- } \\
\text { VED } \\
\text { Matrisi } \\
\end{array}$} & \multicolumn{3}{|c|}{ V } & \multicolumn{3}{|c|}{$\mathbf{E}$} & \multicolumn{3}{|c|}{ D } & \multirow{2}{*}{$\begin{array}{l}\text { Toplam } \\
\text { Miktar }\end{array}$} & \multirow{2}{*}{$\begin{array}{l}\text { Toplam } \\
\text { (TL) }\end{array}$} \\
\hline & Matris & $\begin{array}{c}\text { Stok } \\
\text { Miktarı }\end{array}$ & $\begin{array}{c}\text { Stok Değeri } \\
\text { (TL) }\end{array}$ & Matris & $\begin{array}{c}\text { Stok } \\
\text { Miktarı }\end{array}$ & $\begin{array}{c}\text { Stok Değeri } \\
\text { (TL) }\end{array}$ & Matris & $\begin{array}{c}\text { Stok } \\
\text { Miktarı }\end{array}$ & $\begin{array}{c}\text { Stok } \\
\text { Değeri } \\
\text { (TL) }\end{array}$ & & \\
\hline A & AV & 2 & $59.134,38$ & AE & 12 & $440.237,07$ & AD & 0 & 0 & 14 & 499.371,45 \\
\hline B & BV & 9 & $58.513,78$ & BE & 10 & $65.697,26$ & BD & 4 & $27.255,97$ & 23 & $151.467,01$ \\
\hline C & $\mathrm{CV}$ & 58 & $21.606,76$ & $\mathrm{CE}$ & 66 & $33.523,69$ & CD & 42 & $18.781,46$ & 166 & 73.911,91 \\
\hline Toplam & & 69 & \begin{tabular}{|l}
$139.254,92$ \\
\end{tabular} & & 88 & $539.458,02$ & & 46 & $46.037,43$ & 203 & $724.750,37$ \\
\hline
\end{tabular}

Tablo 4'te görüldüğü üzere, ABC-VED matrisi neticesinde $A B C$ ve VED yöntemlerindeki grupların bir araya getirilmesi ile 9 alt kategori oluşturulmuştur. Oluşturulan alt kategorilere göre, 2020 yılında yapılan 724.750,37 TL'lik tıbbi sarf malzeme harcamas1 toplam harcama içindeki payı en çok olandan en az olana doğru; AE (440.237,07 TL), BE (65.697,26 TL), AV (59.134,38 TL), BV (58.513,78 TL), CE (33.523,69 TL), BD (27.255,97 TL), CV (21.606,76 TL), ve CD (18.781,46 TL) şeklinde siralandığı görülmektedir. Alt 
kategorilerde bulunan stok miktarına göre ise; $\mathrm{CE}$ (66), CV (58), CD (42), AE (12), BE (10), BV (9), BD (4) ve AV (2) şeklinde bir sıralama oluşmuştur. En yüksek maliyetli (A) ancak hayati öneme sahip olmayan isteğe bağl1 (D) sarf malzemelerin bulunduğu AD grubunda herhangi bir malzemenin bulunmadığ tespit edilmiştir.

Alt kategorilerde yer alan tıbbi malzemeler ABC-VED Matris yöntemine göre 3 temel kategoride birleştirilmiş ve Tablo 5’te sunulmuştur.

Tablo 5. ABC-VED Matris Analizi Kategorileri

\begin{tabular}{|c|c|c|c|c|c|}
\hline \multicolumn{2}{|r|}{ KATEGORİ } & \multirow{2}{*}{$\begin{array}{c}\text { Stok Miktarı } \\
81\end{array}$} & \multirow{2}{*}{$\begin{array}{c}\begin{array}{c}\text { Stok Miktarı } \\
\mathbf{( \% )}\end{array} \\
39,90\end{array}$} & \multirow{2}{*}{\begin{tabular}{|l} 
Stok Değeri \\
$579.491,99$ \\
\end{tabular}} & \multirow{2}{*}{$\begin{array}{c}\text { Stok Değeri } \\
\text { (\%) } \\
79,96\end{array}$} \\
\hline I & $A V+A E+A D+B V+C V$ & & & & \\
\hline II & $B E+C E+B D$ & 80 & 39,41 & $126.476,92$ & 17,45 \\
\hline III & CD & 42 & 20,69 & $18.781,46$ & 2,59 \\
\hline & Toplam & 203 & 100 & 724.750,37 & 100 \\
\hline
\end{tabular}

Tıbbi sarf malzemelerin hem yüksek maliyetli hem de hasta tedavisi için yüksek hayati önem arz eden kritikliğe sahip olanları I. Kategoride sınıflandırılmıştır. Söz konusu sarf malzemelerin toplam stok miktarı içindeki payı \%39,90 (81 kalem) ve toplam harcama içindeki payı ise \%79,96 (579.491,99 TL) olarak gerçekleşmiştir. Sarf malzemelerin hizmet sunumunun kaliteli bir şekilde sürdürülebilmesi için gerekli olan ve orta düzey maliyete sahip olanlarının yer aldığı II. Kategori, miktar olarak toplam sarf malzemenin \%39,41 (80 kalem)'ini, toplam harcamanın ise \%17,45 (126.476,92 TL)'ini ihtiva etmektedir. III. Kategori, maliyet ve hayati önem açısından düşük değere sahip sarf malzemelerin bulunduğu gruptur. Kategoride bulunan sarf malzemeler miktar olarak toplamın \%20,69 (42 kalem)'unu, maliyet olarak ise toplam harcamanın sadece \%2,59 (18.781,46 TL)'unu ifade etmektedir.

\section{SONUÇ}

İnsan hayatı için temel gereksinim olarak ifade edilen sağlık hizmetlerinin sunumu kaliteli ve kesintisiz bir şekilde yapıldığı sürece etkindir. Kaliteli ve kesintisiz sağlık hizmetinin sunulabilmesinde en önemli anahtarlardan birisi de ihtiyaç duyulan altyapı, teçhizat ve malzemenin yönetilmesidir. 2019 yılında başlayan Covid-19 salgını ile ortaya çıkan hasta yoğunluğu, sağlık kuruluşlarında önemli değişikliklerin yapılmasını zorunlu kılmıştır. Birçok hastanede daha önce farklı branşlarda hizmet veren servisler Covid-19 servisine dönüştürülmüştür. Yaşanan yoğunluk, söz konusu servislerde hastalara hizmet sunumu sırasında kullanılan tıbbi sarf malzemelerin siparişlerini, stoklanmasını ve tüketilmesini de daha önemli hale getirmiş̧tir. Stok yönetimi çerçevesinde, asgari ve optimal sipariş miktarının belirlenmesi, stokların önem düzeyine göre takip ve kontrol edilmesi gerekmektedir. Stok yönetim tekniklerinden ABC analizi, VED analizi ve ABC-VED Matris Analizi stokların etkin yönetimi için geliştirilen yöntemlerdendir. Bu çalışmada, Erzincan Mengücekgazi Eğitim ve Araştırma Hastanesi'nin Covid-19 servislerinde 2020 yllında tüketilen tıbbi sarf malzemeler veri seti olarak alınmış ve etkin stok yönetimi için söz konusu yöntemler kullanılarak analiz edilmiş̧ir. 
Araştırma kapsamında yapılan analizler sonucunda, hastanenin Covid-19 servislerinde 2020 yılında 203 adet tıbbi sarf malzeme kullanıldığ harcamanın 724.750,37 TL olduğu belirlenmiştir.

Stokların toplam harcama içindeki kümülatif payına göre gruplandırıldığı ABC analizinde, kullanılan tıbbi sarf malzemelerin \%68,90'1 maliyetin en yüksek olduğu, dolayısıyla sıkı şekilde takip edilmesi gereken stokların yer aldığı A grubunda, \%20,90'^ orta düzeyde maliyeti ifade eden ve A grubuna göre daha az kontrol gerektiren stokların yer aldığ B grubunda, \%10,20'si ise en düşük maliyetli ve düşük stok kontrolü gerektiren stokların yer aldığ $\mathrm{C}$ grubunda sınıflandırılmıştır.

Stokların hasta hayatı için taşıdığı öneme göre sınıflandırıldığı VED analizinde, tıbbi sarf malzeme stoklarının \%19,21'i hasta hayatı için yüksek öneme sahip olup titizlikle takip edilmesi gereken stokların yer aldığı $\mathrm{V}$ grubunda, \%74,43'ü hasta hayatı için orta düzeyde öneme sahip olan ve dolayısıyla orta düzeyde stok takibi gerektiren stokların bulunduğu E grubunda ve \%6,36's1 ise hasta hayatı için risk teşkil etmeyen, isteğe bağlı olarak stokta tutulan ve düşük stok takibi gerektiren stokları ihtiva eden D grubunda sınıflandırıldığı tespit edilmiştir.

ABC analizi ve VED analizi sonuçları birlikte değerlendirildiğinde, yüksek maliyetli malzemelerin bulunduğu A grubunda sınıflandırılan 14 kalem malzemenin 2'sinin; orta düzey maliyetli malzemelerin bulunduğu B grubunda sınıflandırılan 23 kalem malzemenin 9'unun; düşük maliyetli $\mathrm{C}$ grubu malzemelerden ise 166 kalem malzemenin 58'inin en yüksek hayati önemi arz eden V grubunda da yer aldığı belirlenmiştir. Özellikle, $\mathrm{C}$ grubu düşük maliyetli malzemelerin önemli bir kısmının hayati önem taşıyan $\mathrm{V}$ grubu malzemelerden olması nedeniyle, malzemelerin hem maliyetlerinin hem de hayati önem düzeylerinin bir arada değerlendirilmesi gerektiği tespit edilmiştir. Bu sonuç, sadece maliyetlere göre sınıflandırma yapılarak stok takibi yapılması durumunda, düşük maliyetli stok kalemleri içerisinde yer alan hayati öneme sahip malzemelerin tedarikinde, stoklanmasında ve sağlik hizmetlerinin sunumunda aksaklıklar yaşanabileceği şeklinde yorumlanabilir.

Stokların sadece maliyetlerine göre sınıflandırılması hasta hayatı için önem arz eden bir stokun temini ve bulundurulmasında aksaklıklar yaşanmasına sebep olabilir. Ayrıca, stokların sadece hasta hayatı için taşıdığ gereksiz maliyetlerle karşı karşıya kalmasına neden olabilir. Bu sorunların yaşanmaması için her iki kriterin bir arada ele alınması gerektiği gerçeğinden hareketle yapılan ABC-VED matris analizine göre tıbbi sarf malzemeler 3 kategoriye ayrılarak sonuçlar aşağıda sunulmuştur.

Kategori I'de yer alan malzeme tutarı toplam harcamanın \%79,96'sıdır. Hastane yönetimleri, Kategori I'de sınıflandırılan malzemelerin hayati önem taşıması ve maliyetlerinin yüksek olması nedeniyle, söz konusu malzemeleri ihtiyaç duyulan miktarda, istenilen zamanda ve uygun fiyatla temin ederek stokta bulundurulmasindan sorumludurlar. $\mathrm{Bu}$ kategoride yer alan malzemelerin optimal sipariş miktarı, stok tedarik süresi ve emniyet stoku seviyesi gibi faktörler dikkate alınarak düzenli olarak takip edilmesi ve sıkı bir şekilde denetlenmesi gerekmektedir. Pandemi sürecinde, hastanede kullanılan malzemelerin maliyetlerinin ve önem düzeylerinin değişmesi nedeniyle Kategori I'de yer alan kalemlerin daha dikkatli bir şekilde takibi yapılmalıdır. 
Kategori II'de sınıflandırılan tıbbi sarf malzeme tutarı toplam harcamanın \%17,45'idir. Kategori II'de, sağlık hizmetlerinin sürdürülebilirliğinin sağlanması için gerekli olan malzemeler yer almaktadır. Bu kategorideki malzemeler Kategori I'e kıyasla hasta hayatı açısından daha az öneme sahiptir. Fakat, sağlık hizmetlerinin sunumunda aksaklıklar yaşanmaması için bu malzemelerin de tüketim ve stok düzeyleri ile stok yönetimini etkileyebilecek diğer faktörler göz önüne alınarak takip edilmesi gerekir.

Kategori III'te bulunan tıbbi sarf mazleme tutarı toplam harcamanın sadece \%2,59’udur. Bu kategorideki malzemeler, maliyet ve hayati önem düzeyi düşük olan, stokta tutulması isteğe bağlı olan ve genellikle sağlık çalışanlarının vaka özelinde kullandıkları malzemelerdir. Hastane yönetimlerinin bu kategoride yer alan malzemeler için düşük seviyede bir stok kontrolü yapmaları yeterlidir.

Yapılan analizler dikkate alındığında çalışmada hastane yönetimlerinin stok kontrolünü etkin bir şekilde yürütülebilmesi için şu öneriler ifade edilebilir:

- $\quad$ Kategori I'de yer alan tıbbi sarf malzemelerin hem maliyet hem de hasta hayat1 için taşıdığı öneme binaen tedarik süreçleri izlenmeli, alternatif tedarikçiler tespit edilerek yaşanılabilecek aksaklıkların önüne geçilmelidir. Bu kategoride yer alan AE, BE, AV ve BV grubu tıbbi sarf malzemelerin diğer gruplara göre daha fazla özenle izlenmesi gerekmektedir.

- Hastane Bilgi Yönetim Sistemi aracılı̆̆ ile ilgili tüm birimlerin koordinasyonunda stok tanımlama ve takipleri yapılmalı, belirlenen esaslar dahiline azalan stoklar için uyarı mekanizmaları kurulmalı ve takip edilmelidir.

- $\quad$ Maliyetlerin düşürülebilmesi için tıbbi sarf malzemeler için toplu alım sözleşmeleri yapılmalıdır. Ancak, stok yığılması ve buna bağlı olarak artan stok maliyetleri ile yüzleşmemek için teslimatlar belirlenen yöntem dahilinde partiler halinde alınmalıdır.

$\mathrm{ABC}$ yöntemi hastanenin tıbbi malzeme stoklarını maliyetlerini esas alarak, VED yöntemi ise tedavi gören hastalar için sahip olduğu kritiklik düzeyini esas alarak sınıflandırmıştır. ABC-VED matris yöntemi ise tıbbi malzeme stoklarının yönetiminde hem maliyetin hem de kritikliğin dikkate alındığı yöntem olarak dikkat çekmektedir. Hastane yönetimlerinin pandemi döneminin koşullarını da dikkate alarak stok yönetim ve kontrolünü ABC-VED matris yöntemine göre yapması önerilmektedir.

\section{KAYNAKLAR}

Akman, Mustafa (2003), Hastanelerde Lojistik Yönetim, Nobel Tıp Kitabevleri, İstanbul.

Aytekin, Sinan (2009), “Tam Zamanında Stok Yönetimi Just-In-Tıme Felsefesinin Hastane İsletmelerine Uygulanabilirliği ve Bir Üniversite Hastanesi Örneği”, Balıkesir Üniversitesi Sosyal Bilimler Enstitüsü Dergisi, 12(21), ss. 102-115.

Berman, Howard J. - Weeks, Lewis E. (1992), "The Financial Management Of Hospitals Administration”, On Press, Newyork. 
Böker, Zehra - Çetin, Onur (2020), "Sağlık Sektöründe ABC-VED AHP ve Topsis Yöntemleri Kullanılarak Çok Kriterli Stok Sınıflandırması”, Marmara Üniversitesi Öneri Dergisi, 15(53), ss. 178-208.

Çabuk, Yasemin - Babacan, Atilla - Gürel, Ali (2018), “Hastanelerde ABC ve VED Analizi ile Stok Yönetimi”, Balkan and Near Eastern Journal of Social Sciences, 4(01), ss. 6781.

Çelikçapa, Feray Odman - Şenol, Gökhan (2015), Üretim Yönetimi, Ekin Basım Yayın Dağıtım, Bursa.

Çil Koçyiğit, Seyhan - Doğan Çulha, Emine (2020), "Hastanelerde Stok Kontrol Faaliyetlerinin ABC ve VED Analizleriyle Değerlendirilmesi: Bir Özel Hastane Örneği”, Muhasebe ve Denetime Bakış Dergisi, 20(60), ss.37-56.

Dağsuyu, Cansu (2019), "Bulanık ABC-VED Analizi ile Metal Sektöründe Stok Sınıflandırması”, Uludağ Üniversitesi Mühendislik Fakültesi Dergisi, 24(3), ss. 211220.

Dunford, Rosie - Su, Quanrong - Tamang, Ekraj - Wintour Abigail (2014), "The Pareto Principle”, The Plymouth Student Scientist, 7(1), pp. 140-148.

Fitriana, Ida - Satria, Raden Gagak Donny - Setiawan, Dwi Cahyo Budi (2018), "Medicine Inventory Management by ABC-VED Analysis in the Pharmacy Store of Veterinary Hospital”, Asian Journal of Animal and Veterinary Advances, 13(1), pp. 85-90.

Gupta R. - Gupta K.K. - Jain B.R. - Garg G.R. (2007), “ABC and VED Analysis in Medical Stores Inventory Control”, Medical Journal Armed Forces India, 63(4), pp. 325-327.

Huarng, Fenghueih (1998), Hospital Material Management in Taiwan: A Survey, Hospital Materiel Management Quarterly, 19(4), pp. 71-81.

Hussain, Mansoor - Siddharth, Vijaydeep - Arya, Sanjay (2019), “ABC, VED and Lead Time Analysis in The Surgical Store of A Public Sector Tertiary Care Hospital in Delhi”, Indian Journal of Public Health, 63(3), pp. 194-198.

Işıkçelik, Ferda - Özkan, Okan - Ağırbaş, İsmail (2019), "Hastane İlaç Stoklarının ABC, VED ve ABC-VED Yöntemleri İle Analizi”, Hacettepe Sağlık İdaresi Dergisi, 22(2), ss. 305-318.

Karagöz, Fırat - Yıldız, Mehmet Selami (2015), "Hastane İşletmelerinde Stok Yönetimi İçin ABC ve VED Analizlerinin Uygulanması", Yönetim ve Ekonomi Araştırmaları Dergisi, 13(2), ss. 375-396.

Kılıç, Mustafa - Öztürk, Hatice (2006), "Hastanelerde Mesai Saatleri Dışında Yürütülen Yönetim Hizmetleri: Ankara İli Eğitim Hastanelerinde Bir Alan Araştırması”, Hacettepe Sağlık İdaresi Dergisi, 9(1), ss 55-79. 
Manhas Anil K. - Aubid, Malik - Haroon, Rashid - Sheikh Mushtag A. ve Syed, A.T. (2012), “Analysis of Inventory Drug and Pharmacy Department of a Tertiary Care Hospital”, Analysis, 25(3), pp. 183-185.

Rachmania, Ilma Nurul - Basri, Mursyid Hasan (2013), "Pharmaceutical Inventory Management Issues in Hospital Supply Chains”, Management, 3(1), pp. 1-5.

Reddy, V. Venkat (2008), “Managing a Modern Hospital: Hospital Materials Management”, Edited by Srinivasan, Sage Publications Inc, California, USA.

Roy, Rabindra Nath - Manna, Saikat - Sarker, Gautam Narayan (2010), “Applying Management Techniques for Effective Management of Medical Store of a Public Sector Undertaking Hospital”, Indian Journal Prev. Soc. Med, 41(1), pp. 1114.

Savaş, Hüseyin Okan (2018), Özel Bir Hastanenin Ameliyathanesinin Stok Kontrolünde ABC, VED ve ABC-VED Matriks Analizinin Kullanımı, (Yayınlanmamış Yüksek Lisans Tezi), İstanbul Yeniyüzy1l Üniversitesi, İstanbul.

Taddele, Biruk Wogayehu - Wondimagegn, Ayalewu Adinewu - Asaro, Mulugeta Asfaw Sorato, Mende Mensa - Gedayi, Bisrat Gissila - Hailesilase, Anidinet Assefa (2019), "ABC-VEN Matrix Analysis of The Pharmacy Store in A Secondary Level Health Care Facility in Arbaminch Town”, Journal of Young Pharmacists, 11(2), pp. 182-185.

Tanyaş, Mehmet - Baskak, Murat (2013), Üretim Planlama ve Kontrol, İrfan Yayıncılık, İstanbul.

Tengilimoğlu, Dilaver (2015), “Sağlık Hizmetlerinde Pazarlama Karması Elemanları ve Özellikleri”, Ankara Üniversitesi SBF Dergisi, 55 (1), ss. 187-202.

Tengilimoğlu, Dilaver - Yiğit, Vahit (2017), Sağlık İşletmelerinde Tedarik Zinciri ve Malzeme Yönetimi, Nobel Yayıncılık, Ankara.

Tersine, Richard J. - Tersine, Michele G. (1988), Instructor's Manual to Principles of Inventory and Materials Management, North-Holland.

Tisinli, Ayla - Savaş, Okan (2019), "Ameliyat Odalarında Stok Kontrol Yöntemleri: ABC, VED ve ABC-VED Matriks Analizi”, Sağlık ve Hemşirelik Yönetimi Dergisi, 6 (2), Ss. 101-109.

Türk, Murat ve Şeker, Mustafa (2011), "Stratejik Stok Yönetimi: Bir Kamu Hastanesi Örneği”, Uluslararası İnsan Bilimleri Dergisi, 8(1), ss. 713-727.

Yarar, Onur - İnce, Özgür (2017). Sağlık Kuruluşlarında Hasta Hizmetleri, Güneş Tıp Kitabevleri, Ankara

Y1lmaz, Faruk (2018), "The Drug Inventories Evaluation of Healthcare Facilities Using ABC And VED Analyzes”, Istanbul Journal of Pharmacy, 48(2), pp. 43-48. 
Yiğit, Arzu - Yiğit, Vahit (2019), “T1bbi Malzeme Stok Kontrolünde ABC ve VED Analizi: Sağlık Bakanlığı Hastanelerinde Bir Araştırma”, Süleyman Demirel Üniversitesi Vizyoner Dergisi, 10(24), ss. 254-263.

Yiğit, Vahit (2014), “Hastanelerde Stok Kontrol Analizi: Akdeniz Üniversitesi Hastanesinde Bir Uygulama”, Sayıştay Dergisi, 93, ss. 105-128. 
